\section{ENZYMATIC DEGRADATION OF PEPSTATIN A TO A NEW TETRAPEPTIDE}

Sir :

Pepstatins are acid-protease inhibitors produced by Streptomyces testaceus, S. argenteolus var. toyonakensis and $S$. parvisporogenes ${ }^{1-3)}$. Isolation, characterization, chemical synthesis and biological properties of pepstatins have been thoroughly studied by UMEZAwA et al. ${ }^{1 \sim 7,9 \sim 11)}$ and Gross et al. ${ }^{8)}$ Pepstatins are $\mathrm{N}$-acyl derivatives of a pentapeptide and their general structural formula can be shown as follows: R-L-valyl-L-valyl-4-amino-3-hydroxy6-methylheptanoyl-L-alanyl-4-amino-3-hydroxy-6-methylheptanoic acid (R-Val-ValAHMHA-Ala-AHMHA).

The following fatty acid moieties have been described for various pepstatins: pepstatin $\mathrm{A}$, $\mathrm{R}=$ iso-valeryl; $\mathrm{B}, \mathrm{R}=n$-caproyl; $\mathrm{C}, \mathrm{R}=i$ isocaproyl; $\mathrm{D}, \quad \mathrm{R}=n$-heptanoyl; $\mathrm{E}, \mathrm{R}=i$ soheptanoyl; $\mathrm{F}, \mathrm{R}=$ anteiso-heptanoyl; $\mathrm{G}, \mathrm{R}=$ n-capryl; $\mathrm{H}, \mathrm{R}=$ iso-capryl; $\mathrm{Ac}, \mathrm{R}=$ acetyl; $\mathrm{Bu}, \mathrm{R}=n$-butyryl and $\mathrm{Pr}, \mathrm{R}=$ propionyl. All these pepstatins are almost equally active in inhibiting pepsin and cathepsin D, but the activity to inhibit renin increases with the increase of the number of carbon atoms in the fatty acid moietys, ${ }^{8)}$. It suggests that modification of the fatty acid moiety or acylvalyl moiety will provide new and more useful pepstatin analogues.

We attempted to find an enzyme for specific cleavage of the fatty acid group from pepstatins and discovered such an enzyme in several microorganisms. In this communication we report enzymatic degradation of pepstatin A by Bacillus sphaericus.

Enzyme activity was assayed by gas chromatographic analysis of iso-valeric acid liberated from pepstatin A. A unit of the enzyme is defined as an amount necessary for liberating one nanomole of iso-valeric acid per minute at $37^{\circ} \mathrm{C}$.

A strain (B400) of B. sphaericus was grown at $30^{\circ} \mathrm{C}$ with shaking $(125 \mathrm{rpm})$ on a reciprocal shaking machine in $50 \mathrm{ml}$ of the following medium placed in a 500-ml SAKaGuchi flask: $1 \%$ glucose, $1 \%$ peptone, $1 \%$ yeast extract and $0.3 \% \mathrm{NaCl}, \mathrm{pH}$ 7.0. Cell growth and the enzyme activity (enzyme preparation: toluenized cells) were measured. The maximum cell growth was obtained in the first 30 hours. The enzyme activity of total cells increased during the period parallel to the growth and this increase continued thereafter for $15 \sim 25$ hours. The maximum activity per cell was obtained at around 55 hours of the culture. Inducible formation of the enzyme was not observed in the presence of the substrate. Addition of pepstatin A to the medium at the concentration of $0.5 \mathrm{mg} / \mathrm{ml}$ or $2 \mathrm{mg} / \mathrm{ml}$ at the start of the growth or at 16 hours after inoculation did not give any effect on the enzyme activity per cell and the cell growth (Fig. 1).

Fig. 1. Time course of cell growth and enzyme production by Bacillus sphaericus

Pepstatin A is added at the start of the cultivation. Other conditions are given in the text.

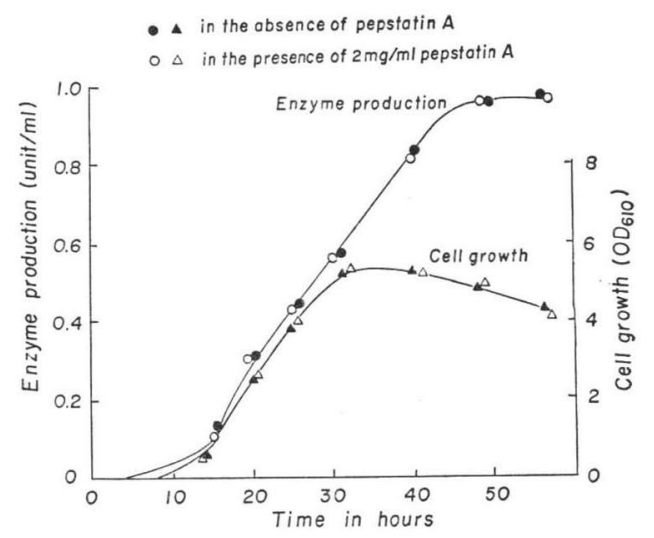

Incubation of pepstatin $\mathrm{A}$ with washed and toluenized cells or cell-free extract obtained by passage through a French press resulted in release of iso-valeric acid from the substrate. The disappearance of this activity after heating the preparations at $100^{\circ} \mathrm{C}$ for 10 minutes indicates enzymatic degradation and excludes the possibility of chemical or spontaneous decomposition of pepstatin A (Table 1). Purification and properties of the enzyme are given in the succeeding paper. ${ }^{12)}$ The reaction was also monitored by formation of ninhydrin-positive products in thinlayer chromatography. Pepstatin $\mathrm{A}$ in which its N-terminal is acylated is ninhydrin-negative, but after the incubation two new spots of Rfs. 0.36 and 0.67 appeared in thin-layer 
Table. 1. Degradation of pepstatin A by toluenized cells and cell-free extract from Bacillus sphaericus

\begin{tabular}{|c|c|c|c|c|c|c|}
\hline \multirow{3}{*}{ Cell preparations } & \multicolumn{2}{|c|}{$\begin{array}{c}\text { iso-Valeric acid } \\
(\mu \mathrm{mole} / \mathrm{ml})\end{array}$} & \multicolumn{4}{|c|}{ Ninhydrin-positive spot } \\
\hline & \multirow{2}{*}{$\begin{array}{c}\text { Before } \\
\text { incubation }\end{array}$} & \multirow{2}{*}{$\begin{array}{c}\text { After } \\
\text { incubation }\end{array}$} & \multicolumn{2}{|c|}{ Before incubation } & \multicolumn{2}{|c|}{ After incubation } \\
\hline & & & Rf 0.36 & Rf 0.67 & Rf 0.36 & Rf 0.67 \\
\hline Toluenized cells & 0.0 & 1.53 & - & - & + & + \\
\hline Heated toluenized cells & 0.0 & 0.0 & - & - & - & - \\
\hline Cell-free extract & 0.0 & 1.60 & - & - & + & + \\
\hline Heated cell-free extract & 0.0 & 0.0 & - & - & - & - \\
\hline
\end{tabular}

A mixture $(1 \mathrm{ml})$ of $3.64 \mu$ moles of pepstatin A, $50 \mu$ moles of phosphate buffer, $\mathrm{pH} 7.0,0.25 \mathrm{ml}$ of toluenized cells or a cell-free extract and a drop of toluene was incubated at $37^{\circ} \mathrm{C}$ for 16 hours.

The toluenized cells added to the mixture were prepared as follows: Cells were harvested at 55 hours of the culture and washed with cold $0.01 \mathrm{~m}$ phosphate buffer, pH 7.0 twice. The washed cells were suspended in the same buffer to give $\mathrm{OD}_{610} 1450$, and mixed with toluene $(0.5 \%)$. After gentle stirring for 15 minutes at room temperature. The cell suspension was used as toluenized cells.

The cell-free extract was prepared by passing the cell suspension through a French press and centrifuging the resulted homogenate at $10,000 \times g$ for 20 minutes. The final concentration of the cell-free extract in the reaction mixture was $1 \mathrm{mg} / \mathrm{ml}$ as protein. For iso-valeric acid analysis, the reaction mixture was acidified with $\mathrm{H}_{2} \mathrm{SO}_{4}$ and extracted with ether.

Gas chromatography was made using $n$-valeric acid as an internal standard.

chromatography using a silica gel plate (Silica gel G Art 7515, E. Merck) and $n$-butanol-acetic acid-water (4:1:1). One of them ( $\operatorname{Rf} 0.36)$ was identified to be valine by the $\mathrm{Rf}$ value and co-chromatography with an authentic Lvaline. Another degradation product of $\mathrm{Rf}$ 0.67 showed a bluish purple spot and slow colorization in ninhydrin reaction.

The Rf 0.67 product was isolated by the following procedure: A mixture containing $3.4 \mathrm{~g}$ of pepstatin A dissolved in 2 liters of dist. water adjusted to $\mathrm{pH} 7.2,500 \mathrm{ml}$ of the cell-free extract (protein: $74 \mathrm{mg} / \mathrm{ml}$ ), $\mathrm{pH} 7.2$ and a few drops of toluene to prevent bacterial contamination, was incubated at $37^{\circ} \mathrm{C}$. After 16 hours the reaction mixture was adjusted to $\mathrm{pH} 2$ with $\mathrm{HCl}$ and filtered. The precipitate was washed twice with $500 \mathrm{ml}$ of $0.01 \mathrm{~N} \mathrm{HCl}$. The filtrate and the washings were combined and applied onto a Dowex $50 \times 4$ column $(250 \mathrm{ml})$. The column was washed with 10-fold column volume of dis-

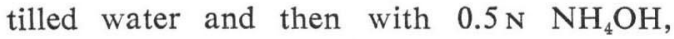
successively. Anti-pepsin activity was assayed according to the method described by AOYAGI et $a l .^{\left.{ }^{\circ}\right)}$ and ninhydrin reaction was checked on eluted fractions. The fractions which showed a weak anti-pepsin activity were combined and concentrated in vacuo to $300 \mathrm{ml}$, and extracted with two equal volumes of $n$ - butanol. The butanol layer was evaporated to dryness and the residue was dissolved in methanol. In order to remove amino acids, the methanol solution was applied onto a Sephadex LH-20 column $(5 \times 90 \mathrm{~cm})$. The fractions with weak ninhydrin-positive and anti-pepsin activity were combined and evaporated. The residue was dissolved in $5 \mathrm{ml}$ of chloroform-methanol mixture (1:1) and crystallized: crude crystals, $1.1 \mathrm{~g}$. Recrystallization gave $916 \mathrm{mg}$ of colorless crystals.

The crystals $\left(\mathrm{mp} 171 \sim 172^{\circ} \mathrm{C}\right.$, colored at $168^{\circ} \mathrm{C},[\alpha]_{\mathrm{D}}^{23}-51.0^{\circ}$ (c 1.0, methanol), end absorption in UV) gave positive thionyl chloride, hydroxamic acid-ferric chloride, potassium permanganate, RYDON-SMITH and ninhydrin reactions, but negative EHRLICH, SAKAGUCHI, naphthoresorcinol, anisaldehydesulfuric acid reactions. This compound was soluble in methanol, ethanol, pyridine and acetic acid, slightly soluble in $n$-propanol, $n$ butanol, n-amylalcohol and acetone, but insoluble in ether, ethyl acetate and butyl acetate. The following $\mathrm{Rf}$ values were found in thin-layer chromatography using a silica gel plate: 0.67 with $n$-butanol-acetic acid-water (4:1:1), 0.15 with $n$-butanol - butyl acetate acetic acid-water $(4: 1: 1: 1)$ and 0.23 with aqueous $n$-butanol. Migration towards the cathode was observed in high-voltage paper 
electrophoresis at $3,500 \mathrm{~V}$ for 15 minutes with a buffer solution of formic acid-acetic acidwater (25:75:900), pH 1.8. The IR spectrum revealed the amide bonds at 1660 and 1545 $\mathrm{cm}^{-1}$.

Acid hydrolysis of the $\mathrm{Rf} 0.67$ product in $6 \mathrm{~N} \mathrm{HCl}$ at $110^{\circ} \mathrm{C}$ for 20 hours gave three ninhydrin-positive spots in thin-layer chromatography, which corresponded to alanine, valine and 4-amino-3-hydroxy-6-methylheptanoic acid (AHMHA). The amino acid analysis showed that the molar ratio of alanine, valine and AHMHA was 1:1:1.9. None of fatty acids was detected by gas chromatography in the ether extract of the hydrolysate.

These results indicate that the peptide obtained by the enzymatic degradation of pepstatin $\mathrm{A}$ is L-valyl-4-amino-3-hydroxy-6methylheptanoyl-L-alanyl-4-amino-3-hydroxy6-methylheptanoic acid (Val-AHMHA-AlaAHMHA). This structure was confirmed by mass spectroscopy of the acetylated derivative. Thus, the cell-free extract from $B$. sphaericus B400 was confirmed to contain an enzyme which hydrolyzes pepstatin A to iso-valeric acid, L-valine and Val-AHMHA-Ala-AHMHA. The newly obtained tetrapeptide described above still had antipepsin activity with 10 $\mathrm{mcg} / \mathrm{ml}$ as the $50 \%$ inhibition concentration, although the activity is about 1,000 times lower than that of pepstatin $\mathrm{A}^{4)}$.

\section{Hiroshi TONE \\ Norio Shibamoto \\ YoshiYuki Matsushita \\ TAIJI INUI \\ Akira takamatsu}

Central Research Laboratories,

Sanraku-Ocean Co., Ltd.

9-1, Johnan 4-chome,

Fujisawa, Japan

\section{TAKAAKI AOYAGI \\ TOMIO TAKEUCHI \\ Hamao Umezawa}

Institute of Microbial Chemistry, 3-14-23, Kamiosaki, Shinagawa-ku, Tokyo, Japan

(Received September 16, 1975)

\section{References}

1) Umezawa, H.; T. Aoyagi, H. Morishima, M. Matsuzaki, M. Hamada \& T. TAKeUChI: Pepstatin, a new pepsin inhibitor produced by actinomycetes. J. Antibiotics 23: 259 262, 1970

2) Miyano, T.; M. Tomiyasu, H. Iizuka, S. Tomisaka, T. TAKita, T. AOYAgI \& $H$. UMEZAwA: New pepstatins, pepstatins $B$ and $\mathrm{C}$, and pepstanone A produced by streptomyces. J. Antibiotics 25: 489 491, 1972

3) Aoyagi, T.; Y. Yagisawa, M. Kumagai, M. Hamada, H. Morishima, T. Takeuchi \& H. Umezawa: New pepstatins, pepstatins $\mathrm{Bu}, \mathrm{Pr}$ and Ac produced by streptomyces. J. Antibiotics 26: 539 541, 1973

4) Aoyagi, T.; S. Kunimoto, H. Morishima, T. TAKeuchi \& H. Umezawa: Effect of pepstatin on acid proteases. J. Antibiotics 24: $687 \sim 694,1971$

5) Kunimoto, S.; T. Aoyagi, H. Morishima, T. TAKeUchi \& H. Umezawa: Mechanism of inhibition of pepsin by pepstatin. J. Antibiotics 25: 251 255, 1972

6) Aoyagi, T.; H. Morishima, R. Nishizawa, S. Kunimoto, T. Takeuchi, H. Umezawa \& H. IKEZAWA: Biological activity of pepstatin, pepstanone $A$ and partial peptides on pepsin, cathepsin D and renin. J. Antibiotics 25: 689 694, 1972

7) Inezawa, H.; T. Aoyagi, T. Takeuchi \& H. Umezawa: Effect of protease inhibitors of actinomycetes on lysosomal peptide hydrolases from swine liver. J. Antibiotics 24: 488 490, 1971

8) Gross, F.; J. Lazer \& H. Orth: Inhibition of the renin-angiotensinogen reaction by pepstatin. Science 175: 656, 1972

9) Umezawa, H.; T. Miyano, T. Murakami, T. Takita, T. Aoyagi, T. Takeuchi, $H$. Naganawa \& H. Morishima: Hydroxypepstatin, a new pepstatin produced by streptomyces. J. Antibiotics 26: 615 617, 1973

10) Morishima, H.; T. Takita, T. Aoyagi, T. TAKeuchi \& H. UMEZAwA: The structure of pepstatin. J. Antibiotics 23: 263 265, 1970

11) Morishima, H.; T. Takita \& H. UmezaWA: The chemical synthesis of pepstatin A. J. Antibiotics 25: 551 552, 1972

12) Tone, H.; Y. Matsushita, Y. Yagi, A. Takamatsu, T. Aoyagi, T. Takeuchi \& $\mathrm{H}$. UMEZAWA: Purification and properties of pepstatin hydrolase from Bacillus sphaericus. J. Antibiotics 28: 1012 1015, 1975 